\title{
Comparison of Personal Characteristics, Tobacco Use, and Health States in Chaldean, Arab American, and non-Middle Eastern White Adults
}

\author{
H. Jamil · T. Templin · M. Fakhouri • V. H. Rice • \\ R. Khouri · H. Fakhouri
}

Published online: 15 March 2008

(C) Springer Science+Business Media, LLC 2008

\section{Erratum to: J Immigrant Minority Health} DOI 10.1007/s10903-008-9125-7

During the production process, Hasan Al-Omran, Ibrahim Al-Fauori, Omar Baker were incorrectly listed as co-authors of this article; the authors listed above (H. Jamil, T. Templin, M. Fakhouri, V. H. Rice, R. Khouri, and H. Fakhouri) are the authors of this paper.

Virginia Rice and Springer regret the error.

The online version of the original article can be found under doi: 10.1007/s10903-008-9125-7.

H. Jamil · M. Fakhouri · R. Khouri · H. Fakhouri

Arab American \& Chaldean Council (ACC), 28551 Southfield,

Road, Lathrup Village, MI 48076, USA

H. Jamil

Department of Family Medicine \& Public Health Sciences,

Wayne State University, Detroit, MI, USA

T. Templin · V. H. Rice $(\bowtie)$

College of Nursing, Wayne State University, 366 Cohn,

Building, 5557 Cass Avenue, Detroit, MI 48202, USA

e-mail: vrice@wayne.edu 